\title{
Factors Responsible for Cohabitation among Youth as Perceived by Students of the University of Ilorin, Nigeria
}

\author{
Olushola A. Iyekolo
}

\begin{abstract}
Cohabitation is an intimate sexual union between two unmarried partners who share the same living quarter for a sustained period of time. This study investigated factors responsible for cohabitation among youths as perceived by students of University of Ilorin. The research design that was adopted for the study is the descriptive survey method. The population for this study comprises all of the 44,566 undergraduates at the University of Ilorin, while the target population for the study comprises 24,935 students of the Faculties of Arts; a total of two hundred (200) students constitutes the sample of this study. The instrument used for collection of the relevant data for this study was a 20-item structured questionnaire entitled "Factors Responsible for Cohabitation among Youths". The instrument was validated with a reliability coefficient of 0.85 after a test re-test using PPMC at 0.05 alpha level. The findings of this study revealed that: reducing the occurrence of loneliness, improving the academic performance of the cohabitants, it is morally acceptable, it encourages peer reading/study, and it goes against the spiritual principle of purity, among others, are the common factors responsible for cohabitation. Also, there is a significant difference in the factors responsible for cohabitation among youths as perceived by the students of the University of Ilorin on the basis of their faculty, gender, and level. There is no significant difference in the factors responsible for cohabitation among youths as perceived by the students of the University of Ilorin on the basis of their age bracket. Based on the findings of this study, it was recommended that there should be a regular campaign regarding the benefits and dangers associated with students' cohabitation, the Government should support the university management in providing sufficient accommodations for students, students should switch to cohabitation when they don't have any other option and they should not abuse it, and parents should make sure that they are monitoring the activities of their children to avoid the danger of cohabitation.
\end{abstract}

Keywords: Factors, Cohabitation, Youth, Students, University of Ilorin 
Olushola A. Iyekolo, Ph.D., is a Lecturer in the Department of Social Sciences Education at the University of Ilorin, Nigeria and she obtained her Doctor of Philosophy (Ph.D.) in 2013 in Sociology of Education from the University of Ilorin, Nigeria. Iyekolo is a registered teacher with the Teachers' Registration Council of Nigeria (TRCN). She is also a member of the Association of Sociologists of Education in Nigeria, and a Member of the Social Studies Association of Nigeria. Recent publications include: Iyekolo, A. O. (2020). Non-verbal communication and management of interactive conflicts in school-based violence: A sociological perspective. Canadian Journal of Family and Youth, 12(1), 260-268. Available online at https://journals.library.ualberta.ca/cjfy/index.php/cjfy/article/view/29532 Iyekolo, A.O., Okafor, I.P. \& Abdulaziz, I. (2020). Attitude of teachers towards women leadership of secondary schools in Ilorin, Kwara State. Anatolian Journal of Education, 5(1), 135-140. (A Journal of the Faculty of Education, Eskisehir Osmangazi University, Turkey). Available online at http://eaje.net/images/dosyalar/aje_2020_1_13.pdf 


\section{Introduction}

Students need comfortable accommodations in the universities for them to study hard and pass their examinations. The original idea of hostel accommodation was to provide a more conducive academic atmosphere for students. As a result, the first-generation universities built beautiful hostels, befitting the image of undergraduate and postgraduate students. The students' population at that time was within control. In some of the hostels, two or a maximum of three students occupied a room (Guardian, 2004). Abubakar (2007) noted that students are supposed to be accommodated with one person per room. Conflict erupts where two or more students share a room.

Nigerian university students presently live under horrible conditions on campus. Their accommodation is believed to be so bad and insanitary, congested and over-crowded, that it impedes their ability to learn effectively. A room with two wardrobes, which used to be allocated to two students in the past, now accommodates six students. Yet in such an arrangement, not more than $40 \%$ of the students get official accommodation (Otobo, 2002).

Okebukola (2004) opined that in some rooms in Federal and State universities, fifteen students shared space meant for five. In some universities, 24 students stayed in one big room originally meant for 10 students. The number of occupants rose because students frequently squat their friends or relations who would reciprocate such actions in later years. Thus, rooms are often choked up with wears, buys and beguiles, resulting in less space for chairs and desks, making the rooms inadequate for personal study.

Edukugho (2006) claimed that $80 \%$ of the university student population lives outside the campuses with many students becoming victims of shylock landlords and hostile communities, and persistently in bloody confrontations with host indigenes. Ten students or more living in a room is bad enough even in private hostels. Edukugho observed that students' welfare was still a far cry as many of them lived in filthy, congested hostels which denies students their comfort and privacy. Idachaba (2007) opined that the over-bloated admission of students into Nigerian universities results in acute shortages in student accommodations which makes them live in over-crowded rooms. Shalter (1970) asserted that when such a number of youth from different backgrounds all live in a room together, there is always conflict of irreconcilable interest, loyalties, values and opinions.

According to Bacharach and Okho (2000), cohabitation is an intimate sexual union between two unmarried partners, who share the same living quarters for a sustained period of time. Cohabitation, according to Bower and Christopherson (2017), is a union of persons of the opposite sex living together but not married. An increase in the acceptability of cohabitation can be viewed as evidence of the weakening of social norms related to marriage, known as the de-institutionalization of marriage (Bumpass \& Lu, 2012). Cohabitation was obscure and even taboo throughout the nineteenth century and until the 1970's non-marital unions have become common because the meaning of the family has been altered by individualistic social values which have progressively matured since the late 1940's (Ogunsola, 2004).

Students' cohabitation has attracted a lot of policy analysis, academic research and debates in recent times. Students in higher educational institutions are experiencing a critical situation in terms of higher tuition fees and other associated college costs related to facilities and services provision, especially with regard to on-campus accommodation (Aluko, 2009). 
A number of challenges may exist within or outside the educational institutions that predisposes students to cohabitation (Oweh, 2013; Peretomode \& Ugbomeh, 2013).

However, a crucial aspect of these problems in tertiary institutions as related to this study is insufficient accommodation for students within the campus premises. In Nigeria, about two decades ago, the number of university students increased eightfold from 55,000 in 1980 to more than 400,000 in 2002 and is projected to be above the million mark in 2010 (Agbola \& Hanat, 2001; Bollag, 2002).

Therefore, the majority of students in second to penultimate years of studies are forced to live off-campus in communities adjoining their institutions (Onyike \& Uche, 2010; Aluko, 2011; Arisukwu, 2013). Cohabitation is not limited to its prevalence but it is also extended to its widespread and increasing social acceptance and implications on individual wellbeing and academic performance (Popenoe \& Whitehead, 2002).

The high cost of college fees has, in some cases, forced students to cohabit. According to Sassler (2004), many younger cohabiters enter into joint living arrangements as a result of financial need which may result in unstable partnerships. However, other studies have shown that financial distress is a salient predictor of positive aspects of relationship quality, for example, affection, love and satisfaction, (Lichter, 2006). There is evidence that educational attainment can promote positive interactions within cohabiting couples as noted by Sassler (2004).

Studies have shown that economic well-being is positively related to the odds that contribute to cohabiting. However, Onyike (2010) asserted that cohabiters are less likely to pool their income together. This may provide greater flexibility to engage in a wider range of economic arrangements, but this leaves cohabiters more exposed to fluctuations in income. Other studies have found a relationship between objective and subjective measures of financial strain and violent aggression toward female partners (Omonjo, 2014).

Therefore, adjusting to hostel life is easier when expectations are realistic. Many students come into the hostel believing that their roommates will be their friends for life, while the roommates, on the other hand, may see the room only as a place to sleep, since they already have a social network. This leads to hurt feelings, confusion, and tension (Adegboyega, 2018). This study, therefore examines the factors responsible for cohabitation among youths as perceived by students at the University of Ilorin.

\section{Research Question}

This research question was raised and answered in the study:

- What are the factors responsible for cohabitation among youths as perceived by the students at the University of Ilorin? 


\section{Research Hypotheses}

The following hypotheses were formulated and tested in the study:

1. There is no significant difference in the factors responsible for cohabitation among youths as perceived by the students at the University of Ilorin on the basis of gender.

2. There is no significant difference in the factors responsible for cohabitation among youths as perceived by the students at the University of Ilorin on the basis of age bracket.

3. There is no significant difference in the factors responsible for cohabitation among youths as perceived by the students at the University of Ilorin on the basis of level.

4. There is no significant difference in the factors responsible for cohabitation among youths as perceived by the students at the University of Ilorin on the basis of faculty.

5. There is no significant difference in the factors responsible for cohabitation among youths as perceived by the students at the University of Ilorin on the basis of place of residence.

\section{Research Design}

The research design that was used for the study is the descriptive survey method. Survey method is used for descriptive, explanatory and purposes and is therefore most appropriate for this study since the nature of the study entails sourcing for data and analyzing the data to determine the factors responsible for cohabitation among youths.

\section{Population, Sample and Sampling Procedure}

The population for this study comprises all the 44,566 (Unilorin Bulletin 2019) undergraduates at the University of Ilorin, while the target population for the study comprises 24,935 students of the Faculties of Arts, Education, Life Sciences, Physical Sciences, and Social Sciences. Thus, using purposive sampling technique, forty (40) students were drawn from each of the five (5) faculties making a total of two hundred (200) students. This constitutes the sample of this study.

\section{Instrumentation}

The instrument used for collection of the relevant data for this study was a 20-item structured questionnaire entitled; factors responsible for cohabitation among youths. The instrument was developed by the researcher, and it is divided into two (2) sections: A and B. 
Section A elicits the personal data of the respondents while section B deals with factors responsible for cohabitation among youths. The instrument was validated with a reliability coefficient of 0.65 after a test retest using PPMC at 0.05 alpha level. The items in the instrument were structured in a way that they expressed support for cohabitation practices. The instrument was thus formatted on a four (4) point Likert-type scale for scoring the items. The allotment of points is as follows:

Strongly Agree $\quad$ (SA) 4 points

Agree $\quad$ (A) 3 points

Disagree $\quad$ (D) 2 points

Strongly Disagree $\quad$ (SD) 1 point

\section{Method of Data Analysis}

The data postulated were analysed using descriptive and inferential statistics. The hypotheses generated in the course of the study were tested using t-test and Analysis of Variance (ANOVA) statistics. The t-test was used for testing hypotheses 1, 2 and 3 while hypotheses 4 and 5 were analysed using Analysis of Variance (ANOVA) at 0.05 level of significance.

\section{Results}

Demographic Data of the Respondents

A total of 200 questionnaire forms were distributed in order to elicit data to answer the research questions generated in this study. Tables 1-4 focused on the demographic data of the respondents.

Table 1: Percentage Distribution of Respondents Based on Gender

\begin{tabular}{lll}
\hline \multicolumn{1}{c}{ Gender } & Frequency & Percentage \\
\hline Male & 90 & 45.0 \\
Female & 110 & 55.0 \\
Total & $\mathbf{2 0 0}$ & $\mathbf{1 0 0 . 0}$ \\
\hline
\end{tabular}

Source: (Author's field work, 2019) 
Table 1 reveals that out of the 200 respondents that participated in the study, 90 representing $(45.0 \%)$ of the respondents were males, while 110 representing $(55.0 \%)$ of the respondents were females. This revealed that there were more female respondents than male respondents in this study.

Table 2: Percentage Distribution of Respondents Based on Age

\begin{tabular}{lll}
\hline \multicolumn{1}{c}{ Age } & Frequency & Percentage \\
\hline 16-20 years & 90 & 45.0 \\
$21-25$ years & 110 & 55.0 \\
Total & $\mathbf{2 0 0}$ & $\mathbf{1 0 0 . 0}$ \\
\hline
\end{tabular}

Source: (Author's field work, 2019)

Table 2 reveals that out of the 200 respondents that participated in the study, 90 representing $(45.0 \%)$ of the respondents were between the age of 16-20 years, while 110 representing (55.0\%) of the respondents were between the age of 21-25 years. This revealed that majority of the respondents were between the age of 21-25 years.

Table 3: Percentage Distribution of Respondents Based on Level

\begin{tabular}{lll}
\hline \multicolumn{1}{c}{ Level } & Frequency & Percentage \\
\hline 100 & 60 & 30.0 \\
200 & 90 & 45.0 \\
300 & 20 & 10.0 \\
400 & 30 & 15.0 \\
Total & $\mathbf{2 0 0}$ & $\mathbf{1 0 0 . 0}$ \\
\hline
\end{tabular}

Source: (Author's field work, 2019)

Table 3 reveals that out of the 200 respondents that participated in the study, 60 representing (30.0\%) of the respondents were 100 level students, 90 representing $(45.0 \%)$ of the respondents were 200 level students, 20 representing $(10.0 \%)$ of the respondents were 300 level students, while 30 representing $(51.0 \%)$ of the respondents were 400 level students. This showed that majority of the respondents were 200 level students. 
Table 4: Percentage Distribution of Respondents Based on Faculty

\begin{tabular}{lll}
\hline \multicolumn{1}{c}{ Faculty } & Frequency & Percentage \\
\hline Arts & 40 & 20.0 \\
Education & 90 & 45.0 \\
Life Sciences & 30 & 15.0 \\
Physical Sciences & 20 & 10.0 \\
Social Sciences & 20 & 10.0 \\
Total & $\mathbf{2 0 0}$ & $\mathbf{1 0 0 . 0}$ \\
\hline
\end{tabular}

Source: (Author's field work, 2019)

Table 4 reveals that out of the 200 respondents that participated in the study, 40 representing (20.0\%) of the respondents were Faculty of Arts students, 90 representing (45.0\%) of the respondents were Faculty of Education students, 30 representing (15.0\%) of the respondents were Faculty of Life Sciences students, 10 representing $(20.0 \%)$ of the respondents were Faculty of Physical Sciences students, while 20 representing (10.0\%) of the respondents were Faculty of Social Sciences students. This showed that majority of the respondents were Faculty of Education Students.

Table 5: Percentage Distribution of Respondents Based on Place of Residence

\begin{tabular}{lll}
\hline Place of Residence & Frequency & Percentage \\
\hline On-campus & 30 & 45.0 \\
Off-campus & 170 & 55.0 \\
Total & $\mathbf{2 0 0}$ & $\mathbf{1 0 0 . 0}$ \\
\hline
\end{tabular}

Source: (Author's field work, 2019)

Table 5 reveals that out of the 200 respondents that participated in the study, 30 representing $(45.0 \%)$ of the respondents were on-campus students, while 170 representing $(55.0 \%)$ of the respondents were off-campus students. This revealed that majority of the respondents were off-campus students.

\section{Answering the Research Questions}

Research Question: What are the factors responsible for cohabitation among youths as perceived by the students at the University of Ilorin? 


\section{Table 6: Mean and Rank Order on the Factors Responsible for Cohabitation among Youths}

\begin{tabular}{|c|c|c|c|}
\hline Item & Factors responsible for cohabitation & Mean & Rank Order \\
\hline No. & & & \\
\hline 3 & Reducing occurrence of loneliness & 3.50 & $1^{\text {st }}$ \\
\hline 15 & Youths see it as a natural step in the dating process & 3.40 & $2^{\text {nd }}$ \\
\hline 14 & It creates room for youths to spend more time together & 3.40 & $2^{\text {nd }}$ \\
\hline 13 & It gives the youths a foretaste of sexual intercourse & 3.40 & $2^{\text {nd }}$ \\
\hline 12 & It goes against the spiritual principle of purity & 3.40 & $2^{\text {nd }}$ \\
\hline 6 & It encourages peer reading/study & 3.40 & $2^{\text {nd }}$ \\
\hline 5 & It is morally acceptable & 3.40 & $2^{\text {nd }}$ \\
\hline 4 & Improving the academic performance of the cohabitants & 3.40 & $2^{\text {nd }}$ \\
\hline 11 & It is convenient for cohabitants to live together & 3.30 & $9^{\text {th }}$ \\
\hline 8 & preparing cohabitants to get married later in life & 3.30 & $9^{\text {th }}$ \\
\hline 7 & preparing youths for future marriage & 3.30 & $9^{\text {th }}$ \\
\hline 16 & Cohabitation is the best means for mate selection & 3.30 & $9^{\text {th }}$ \\
\hline 1 & saving cost of accommodation & 3.30 & $9^{\text {th }}$ \\
\hline 2 & $\begin{array}{l}\text { Helping youths to monitor their partners thereby securing } \\
\text { their relationship }\end{array}$ & 3.30 & $9^{\text {th }}$ \\
\hline 20 & $\begin{array}{l}\text { It occurs when there is lack of parental attention and } \\
\text { supervision }\end{array}$ & 3.20 & $15^{\text {th }}$ \\
\hline 19 & Peer influence encourages cohabitation & 3.20 & $15^{\text {th }}$ \\
\hline 18 & $\begin{array}{l}\text { Lack of conducive hostel facilities tend to encourage } \\
\text { cohabitation }\end{array}$ & 3.20 & $15^{\text {th }}$ \\
\hline 17 & $\begin{array}{l}\text { The desire for intimacy and sexual intercourse is provided } \\
\text { regularly in cohabitation }\end{array}$ & 3.20 & $15^{\text {th }}$ \\
\hline 10 & It is a good way to test relationship prior to marriage & 3.20 & $15^{\text {th }}$ \\
\hline 16 & Cohabitation is the best means to select marital partner & 3.20 & $15^{\text {th }}$ \\
\hline
\end{tabular}

Source: (Author's field work, 2019)

Table 6 presents the mean and rank order of the respondents on the factors responsible for cohabitation among youths as perceived by the students at the University of Ilorin. The Table indicates that item 3 which states that "reducing occurrence of loneliness" ranked 1st with a mean score of 3.50. Items 15, 14, 13, 12, 6, 5 and 4 which state that "Improving the academic performance of the cohabitants, it is morally acceptable, it encourages peer reading/study, It goes against the spiritual principle of purity, It gives the youths a foretaste of sexual intercourse, It creates room for youths to spend more time together, It creates room for youths to spend more time together, and Youths see it as a natural step in the dating process" ranked 2nd with a mean score of 3.40. Ranked $9^{\text {th }}$ are items $11,8,7,16,1$ and 2 which states that "It is convenient for cohabitants to live together, preparing cohabitants to get married later in life, preparing youths for future marriage, Cohabitation is the best means for mate selection, saving cost of accommodation, helping youths to monitor their partners thereby securing their relationship" with a mean score of 3.30. On the other hand, items 20, 19, 18, 
17, 10 and 16 which state that "It occurs when there is lack of parental attention and supervision, Peer influence encourages cohabitation, Lack of conducive hostel facilities tend to encourage cohabitation, the desire for intimacy and sexual intercourse is provided regularly in cohabitation, it is a good way to test relationship prior to marriage, Cohabitation is the best means to select marital partner" ranked 15th with a mean score of 3.20. Since all the twenty items in the questionnaire ranked above the mid-mean score of 2.50 , then it can be suggested that all the items in the questionnaire are factors responsible for cohabitation among youths as perceived by the students at the University of Ilorin.

\section{Hypotheses Testing}

Hypothesis One: There is no significant difference in the factors responsible for cohabitation among youths as perceived by the students at the University of Ilorin on the basis of gender.

Table 7: Mean, Standard Deviation and t-test Analysis of Difference in the Factors Responsible for Cohabitation among Youths as Perceived by the Students at the University of Ilorin on the Basis of their Gender

\begin{tabular}{llllllll}
\hline Gender & N & Mean & SD & df & Cal.t-value & $\begin{array}{l}\text { P- } \\
\text { value }\end{array}$ & Decision \\
Male & 90 & 3.44 & .36 & & 20.03 & .000 & Rejected \\
Female & 110 & 3.21 & .24 & & & & \\
\hline
\end{tabular}

Source: (Author's field work, 2019)

As shown on Table 7, males had mean score of 3.44 with a standard deviation of .36, while females had mean score of 3.21 with a standard deviation of .24 . The calculated t-value was 20.03 while its calculated significance value is.000 of df $2 / 198$ at alpha level of 0.05 . On this basis, the null hypothesis was therefore rejected. This means that there is a significant difference in the factors responsible for cohabitation among youths as perceived by students of University of Ilorin on the basis of their gender. The reason was that the calculated significance value (.000) is less than 0.05 alpha level ( $\boldsymbol{\rho}>0.05)$.

Hypothesis Two: There is no significant difference in the factors responsible for cohabitation among youths as perceived by students of University of Ilorin on the basis of their age. 
Table 8: ANOVA Summary of Difference in the Factors Responsible for Cohabitation among Youths as Perceived by the Students at the University of Ilorin on the Basis of their Age

\begin{tabular}{lllllll}
\hline Source of Variance & Sum of Squares & df & Mean Squares & F & P-value & Decision \\
\hline Between Groups & .20 & 2 & .20 & 1.92 & .17 & Ho4 \\
Within Groups & 20.71 & 197 & .105 & & & Not Rejected \\
\hline Total & $\mathbf{2 0 . 9 1}$ & $\mathbf{1 9 9}$ & & & & \\
\hline
\end{tabular}

Source: (Author's field work, 2019)

Table 8 shows an F-value 1.92 with a calculated significant .17 at 0.05 alpha level. Since calculated significance .17 is greater than 0.05 alpha level, the hypothesis is thus not rejected. This implies that there is no significant difference in the factors responsible for cohabitation among youths as perceived by the students at the University of Ilorin on the basis of their age.

Hypothesis Three: There is no significant difference in the factors responsible for cohabitation among youths as perceived by the students at the University of Ilorin on the Basis of Level.

Table 9: Analysis of Variance (ANOVA) showing Difference in the Factors Responsible for Cohabitation among Youths as Perceived by the Students at the University of Ilorin on the Basis of their Level

\begin{tabular}{llllll}
\hline Source & Sum of Squares & Df & Mean Squares & Cal. F-ratio & P-value \\
\hline Between Groups & 5.51 & 3 & 1.84 & $23.40 *$ & .000 \\
Within Groups & 15.40 & 196 & .08 & & \\
Total & 20.91 & 199 & & & \\
\hline$* \mathrm{p}<0.05$ & & & & &
\end{tabular}

Table 9 shows an F-value 23.40 with calculated significant .000 at 0.05 alpha level. Since the calculated significance .000 is less than 0.05 alpha level, the hypothesis is thus rejected. This implies that there is a significant difference in the factors responsible for cohabitation among youths as perceived by the students at the University of Ilorin on the basis of their level. In order to determine the mean value(s) that caused the significant difference observed in the ANOVA results of Table 8, the Duncan Multiple Range Test (DMRT) was used as a post-hoc test. The results of the DMRT procedure are displayed in Table 9. 
Table 10: Duncan Multiple Range Test (DMRT) Showing Difference in the Factors Responsible for Cohabitation among Youths as Perceived by the Students at the University of Ilorin on the Basis of their Level

\begin{tabular}{lllll}
\hline Duncan Groupings & N & Mean & Group & Level \\
\hline A & 20 & 3.10 & 1 & 300 level \\
B & 30 & 3.12 & 2 & 400 level \\
C & 90 & 3.30 & 3 & 200 level \\
D & 60 & 3.54 & 4 & 100 level \\
\hline
\end{tabular}

Table 10 shows the Duncan Multiple Range Test indicating the significant difference noted in the ANOVA on Table 8. Group 1 (300 level) with a mean score of 3.10 slightly differed from Group 2 (400 level) with the mean score of 3.12 but significantly differed from Group 3 (200 level) with a mean score of 3.30, and also significantly differed from Group 4 (100 level) with a mean score of 3.54. All the groups differed from one another but the significant difference noted was as a result of Group 1 (300 level). Hence, the significant difference noted in the ANOVA on Table 8 was a result of respondents who are in 300 level. Thus, the hypothesis is rejected.

Hypothesis Four: There is no significant difference in the factors responsible for cohabitation among youths as perceived by the students of University of Ilorin on the basis of their faculty.

Table 11: Analysis of Variance (ANOVA) showing Difference in the Factors Responsible for Cohabitation among Youths as Perceived by the Students at the University of Ilorin on the Basis of their Faculty

\begin{tabular}{llllll}
\hline Source & Sum of Squares & Df & Mean Squares & Cal. F-ratio & P-value \\
\hline Between Groups & 3.40 & 4 & .85 & $9.50^{*}$ & .000 \\
Within Groups & 17.51 & 195 & .09 & & \\
Total & 20.91 & 199 & & & \\
\hline
\end{tabular}

*Significant, $\mathrm{p}<0.05$

Table 11 shows an F-value .85 with a calculated significant .000 at 0.05 alpha level. Since calculated significance .000 is less than 0.05 alpha level, the hypothesis is thus rejected. This implies that there is a significant difference in the factors responsible for cohabitation among youths as perceived by the students at the University of Ilorin on the basis of their 
faculty. In order to determine the mean value(s) that caused the significant difference observed in the ANOVA results of Table 8, the Duncan Multiple Range Test (DMRT) was used as a post-hoc test. The results of the DMRT procedure are displayed in Table 11.

Table 12: Duncan Multiple Range Test (DMRT) Showing the Differences in the Respondents Factors Responsible for Cohabitation among Youths Based on Age

\begin{tabular}{lllll}
\hline Duncan Groupings & N & Mean & Group & Faculty \\
\hline A & 30 & 3.23 & 1 & Life Sciences \\
B & 20 & 3.25 & 2 & Physical Sciences \\
B & 20 & 3.25 & 3 & Social Sciences \\
B & 90 & 3.25 & 4 & Education \\
C & 40 & 3.60 & 5 & Arts \\
\hline
\end{tabular}

Table 9 shows the Duncan Multiple Range Test indicating the significant difference noted in the ANOVA on Table 8. Group 1 (Life Sciences) with a mean score of 3.23 slightly differed from Group 2, 3 and 4 with the mean score of 3.25 but significantly differed from Group 5 with a mean score of 3.60. All the groups differed from one another but the significant difference noted was as a result of Group 1 (Life Sciences). Hence, the significant difference noted in the ANOVA on Table 8 was a result of respondents who are in Faculty of Life Sciences. Thus, the hypothesis is rejected.

Hypothesis Five: There is no significant difference in the factors responsible for cohabitation among youths as perceived by the students at the University of Ilorin on the basis of their place of residence.

Table 13: Mean, Standard Deviation and t-test Analysis of Difference in the Factors Responsible for Cohabitation among Youths as Perceived by the Students at the University of Ilorin on the Basis of their Place of Residence

\begin{tabular}{|c|c|c|c|c|c|c|c|}
\hline $\begin{array}{l}\text { Place } \\
\text { Residence }\end{array}$ & of $\mathbf{N}$ & Mean & SD & df & Cal.t-value & Sig. & Decision \\
\hline On-campus & 30 & 56.18 & 7.19 & \multirow{2}{*}{198} & .96 & .34 & Accepted \\
\hline Off-campus & 170 & 57.35 & 8.22 & & & & \\
\hline
\end{tabular}

Source: (Author's field work, 2019) 
As shown on Table 13, the calculated t value of .96 with a p value of .34 is greater than 0.05 level of significance. This indicates that there was no significant difference in the factors responsible for cohabitation among youths as perceived by the students at the University of Ilorin on the basis of place of residence.

\section{Discussion}

The findings of this study indicated that reducing occurrence of loneliness, improving the academic performance of the cohabitants, it is morally acceptable, it encourages peer reading/study, it goes against the spiritual principle of purity, it gives the youths a foretaste of sexual intercourse, it creates room for youths to spend more time together, it creates room for youths to spend more time together, and youths see it as a natural step in the dating process, are the common factors responsible for cohabitation. The above finding is in line with Ogunbamila (2013) who posited that early young adults were mostly prone to premarital sexual behaviours. Cohabitation is common among undergraduates because many of them are being free for the first time; hence, they tend to enjoy their freedom and independence and are less monitored by either their parents or guardians. Also, Mustapha, Odebode and Adegboyega (2017) further noted that economic well-being is positively related to the odds that contribute to cohabiting. Those who choose to cohabit tend to be of slightly lower socioeconomic status, more liberal, less religious, and are more supportive of egalitarian gender roles and non-traditional family roles. College students who cohabit generally hold a positive attitude about the situation, reporting personal growth, a deeper understanding of one's partner, deeper love, disclosing more and better sex lives. Svodziwa and Kuerten (2017) also found that college students who cohabit have a higher level of general well-being and happiness. Cohabitation among individuals of the opposite sex is a predisposing factor to the initiation of sexual activities (Ogungbanila, 2013).

The findings of this study revealed that there is a significant difference in the factors responsible for cohabitation among youths as perceived by the students at the University of Ilorin on the basis of their gender. This finding is in agreement with that of Ola-Alani (2011) which revealed that cohabitation depends greatly on gender preference, and it has a lasting impact on student academic achievement.

In addition, it was found that there is no significant difference in the factors responsible for cohabitation among youths as perceived by the students at the University of Ilorin on the basis of their age. This finding is in agreement with that of Romano (2006) which revealed that age has nothing to do with the reason for cohabiting. The researcher further submitted that the majority of those engaging in cohabitation are higher institution students. Kezar and Moriarty's (2000) study revealed that young male adults developed cohabitation zeal from the moment they have knowledge of sexual intercourse.

Furthermore, findings revealed that there is a significant difference in the factors responsible for cohabitation among youths as perceived by the students at the University of Ilorin on the basis of their level. On the contrary, the study by Nnamani and Oyibe (2016) revealed that there was no significant different in the factors responsible for cohabitation among secondary school students based on their class. 
It was also discovered that there is a significant difference in the factors responsible for cohabitation among youths as perceived by the students at the University of Ilorin on the basis of their faculty. This finding is in agreement with Musibau and Johnson (2010) whose study revealed that the course of study has no significant influence on students' engagement in cohabitation.

Findings revealed that there is no significant difference in the factors responsible for cohabitation among youths as perceived by the students at the University of Ilorin on the basis of their place of residence. This corroborated the findings of Pat-Mbano et al. (2012) and Adegboyega (2019) who reported that tertiary students reside in off-campus apartments owned by private individuals, pay high rents, and struggle for accommodation with other home-seekers. In order to cut costs, cohabitation has been embraced as one of the alternative accommodation strategies (Umaru et al., 2012; Omonijo et al., 2015; Kasim et al., 2016). This has shaped the behaviour of many students positively and negatively (Svodziwa \& Kurete, 2017). With a shortage of on campus accommodation, students resort to renting offcampus residential buildings. This is common with the public tertiary institution students in Nigeria.

\section{Conclusion}

This research examined the factors responsible for cohabitation among youths as perceived by the students at the University of Ilorin. The findings of this study indicated that reducing occurrence of loneliness, improving the academic performance of the cohabitants, it is morally acceptable, it encourages peer reading/study, it goes against the spiritual principle of purity, it gives the youths a foretaste of sexual intercourse, it creates room for youths to spend more time together, it creates room for youths to spend more time together, and youths see it as a natural step in the dating process, are the common factors responsible for cohabitation. It was also discovered that there is a significant difference in the factors responsible for cohabitation among youths as perceived by the students at the University of Ilorin on the basis of their faculty, gender, and level and that there is no significant difference in the factors responsible for cohabitation among youths as perceived by the students at the University of Ilorin on the basis of their age bracket.

\section{Recommendations}

These recommendations are based on the summary of findings and conclusion reached thereafter.

1. There should be a regular campaign regarding the benefits and dangers associated with students' cohabitation.

2. Government should support the university management in providing sufficient accommodation for students. 
Iyekolo

3. Students should switch to cohabitation when they don't have any other option, and they should not abuse it.

4. Parents should make sure that they are monitoring the activities of their children to avoid the danger of cohabitation. 


\section{References}

Abubakar, T.T. (2007). Cohabitation: A Deadly Trend in Tertiary Institutions. Retrieved February 28th, 2019 from http//.allafrica.com/stories/200809.06049.html.

Adegboyega, L. O. (2018). Practices of contraception among married women in Kwara State: Implications for counselling practice. Tropical Journal of Health Sciences, 25 (4), 34-39.

Adegboyega, L.O. (2019). "Prevalence of Premarital Cohabitation among Teenagers as Perceived by Undergraduates in Kwara State, Nigeria." Covenant International Journal of Psychology, 4(2), 36-48.

Adeoye, A.O., Ola, O., \& Aliu, B. (2012). "Prevalence of Premarital Sex and Factors Influencing it among Students in a Private Tertiary Istitution in Nigeria." International of Psychology and Counselling, 4(1), 6-9.

Alo, A.O. (2008). "Socioeconomics Determinant of Unintended Pregnancies among Yoruba women of Southwest Nigeria." International Journal of Sustainable Development, 1 (4), 145-154.

Alo, O.A \& Akinde, I.S. (2010). "Premarital Sexual Activities in Urban Society of Southwest Nigeria." E.A Journal, 2 (1), 1-16.

Aluko, O.E. (2011). The Assessment of Housing Situation among Students in the University of Lagos. Africa Research Review-An International Multi-Disciplinary Journal, 5 (3), 104-118.

Anderson, K. (2000). Marriage, Family and Sexuality: Probing the Headlines that Impact your Family, Kregel Publications, Grand Rapids, MI.

Arisuku, V. (2013) "University Student Cohabitation; A Regional Comparison of Selected Attitudes and Behaviour." Journal of Marriage and Family Contexts in the United State Population, Vol. 54; 29-41.

Bello, M.O. \& Ogunsanwo, B.A. (2013). "The Psychological Consequence of Cohabitation among Students of Tai Solarin University of Education, Ijagun, Ogun State. Ozean.” Journal of Applied Sciences, 6 (2) 1-6.

Bower. D. \& Christopher, B (2008). Increasing Visibility and Promoting Policy Action of Tackle Sexual Exploitation in and around Schools in Africa. A briefing paper with a focus on west Africa, Dakar plan West.

Chitamun, S. \& Finchilescu, G., (2003). 'Predicting the Intention of South African Female Students to Engage in Premarital Sexual Relations: An Application of the Theory of Reasoned Action." South African Journal of Psychology, 33(3), 154-161.

Crissey, S. R. (2005). "Race / Ethnic Difference in The Marital Expectation of Adolescents: The Role of Romantic Relationships". The Journal of Marriage and Family, 67, 697 - 709.

Cunningham and Thoranton (2004). "The Influence of Parents and Children's Union Transition Attitude towards Cohabitation". Journal of Marriage and Family, Vol. $67,710-720$.

De Van, Qu, Ln and Brown. (2003). "Family Matters, Pre - Marital Cohabitation and Marriage Stability". Journal of Population Reserve, Vol. 22 (1), 99 - 118. 
Dempsey, K. \& Devaus, D. (2004). "Who Cohabits in 2001? The Significance of Age, Gender, Religion and Ethnicity". Journal of Sociology, 40, 157-178.

Ekpenyong, N.S (2002). "Perceived Factors Influencing Premarital Sexual Practice among University Students in Niger Delta University, Bayelsa, Nigeria." Canadian Social Society, 163(2); 153 - 171.

Ekpenyong, N.S. \& Ekpenyong, A.S. (2016). "Perceived Factors Influencing Premarital Sexual Practice among University Students in Niger Delta University, Bayelsa State, Nigeria". Canadian Social Science, 12 (11): 79-88.

Gault-Sherman, M. \& Draper, S. (2012). "What will the Neighbours Think? The Effect of Moral Communities on Cohabitation". Review of Religious Research, 54(1): 45-67.

Joan-Nduta, M. K. (2013). Factors that Contribute to the Prevalence and Practice of Cohabitation among Kenyatta University Students, Nairobi, Kenya. A Thesis Submitted to the School of Environmental Studies and Human Sciences. Kenyatta University for the Award of Degree of Master of Science in Family and Consumer Sciences.

Kate, F. (2010). "Marriage": Examination of the State of Modern Marriage. London: Sheffield Academic Press.

Katz, R. (2001). "Effects of Migration, Ethnicity and Religiosity on Cohabitation". Journal of Comparative Family Studies, 3, 255-269.

Lichter, D.T. (2006). "Marriage or Dissolution? Union transition among Poor Cohabiting Women." Demography, 43, 223-240.

Manning, W.D. \& Cohen, J.A. (2012). "Premarital Cohabitation and Marital Dissolution: An Examination of Recent Marriages." Journal of Marriage and Family, 74, 377387.

Manning, W. D. \& Longmore, M. (2007). “The Changing Institution of Marriage. Adolescent Expectation to Cohabit and Marry". Journal of Marriage and Family, Vol. 69 (3), $559-575$.

Martin, P., Martin, D. \& Martin, M. (2001). "Young Adult Premarital Sexual Activity, Cohabitation and Attitudes towards Marriage. Adolescence, 36, 601-609.

Mashau, T. D., (2006). Unlocking the Mystery of Marriage: Issues in Premarital Counselling. Potchefstroom Theological Publications, Potchefstroom.

Mashau, T. D. (2008). God's Road Map for Human Sexuality: Discipline your Child to make Sexual Choices that Honor God. AcadSA, Kempton Park.

Mustapha, M.L.A, Odebode, A.A. \& Adegboyega, L.O. (2017) "Impact of Premarital Cohabitation on Marital Stability as Expressed by Married Adults in Ilorin, Nigeria." Asia Pacific Journal of Multidisciplinary Research, 5(1), 112-121.

Ofoegbu, C.I. (2002). Human Development, Family Behaviour Parenting, Marriage and Counselling Skills. Enugu: Snapp Press Ltd.

Ogungbamila, A. (2013). "Demographic Predictors of Premarital Sexual Behaviours among Undergraduates." Nigerian Journal of Applied Behavioural Sciences, 1, 68-74.

Ogunsola, M.O. (2004). Premarital Behaviour and Length of Courtship as Determinant of Marital Stability among Couples in Oyo State, Nigeria. Unpublished M.Ed project University of Ibadan, Ibadan. 
Ogunsola, M.O. (2011). "The Effect of Premarital Cohabitation on Quality of Relationship and Marital Stability of Married People in Southwest, Nigeria". African Nebula, Issue 3, 16-24.

Omonijo, D. O. (2014). "Social Analysis of Moral Malpractice Challenges Education Sector in Nigeria.

Onyike, J.A. (2010). "An Assessment of the Management of the Students' Hostels of Tertiary Institutions' in Oweri, Imo State”. Tropical Built Environment. 1 (1): 140.

Patricia, M. (2000). "Marriage Lite": The Risk of Cohabitation and Its Consequences, published by Institute for Study of Civil Society. London: Greener Books.

Popenoe, D. (2009). Cohabitation, Marriage and Child Wellbeing: A Cross-sectional Perspective. The National Marriage Project, Rutgers University.

Rena, R. (2006). "Premarital Sex-lessons from American Experience, Ilorin, Nigeria." The Nigerian Journal of Guidance \& Counselling, 11 (1), 134-155.

Sassler, S. (2004). "The Process of Entering in to Cohabiting Unions". Journal of Marriage and Family. 66(2): 491-505.

Seltzer, J.A. (2004). "Cohabitation in the United States and Britain: Demography, Kinship, and the Future." Journal of Marriage and Family, 66 (4): 921-9.

Seltzer, J.A. (2000). "Families Formed Outside of Marriage". Journal of Marriage and Family, 62(4): 1247-1268. doi: 10.1111/j.1741-3737.2000.01247.x

Smith, D.J. (2004). "Pre - Marital Sex, Procreation and HIV Risk in Nigeria". Studies in Family Planning, Vol, 35 (8): 223 - 235.

Smock, P. J. (2001). "Cohabitation on the United States: An Appraisal of Research Themes, Findings and Implications". Annual Review of Sociology, 26: 1 - 20.

Smock, P.J. (2000). "Cohabitation in the United States: An Appraisal of Research Themes, Findings, and Implications." Annual Review of Sociology, 26:1-20

Sovodziwa, G \& Kurete. T. (2017) "The Psychological Consequences of Cohabitation among Students Tai Solarin University of Education, Ijagun, Ogun State, Nigeria Ozean Journal of Applied Science, 6(2), 65-70.

Stern, O. (2006). "Cohabitation and the Law" Marriage and Family Review, 21, 141 168.

Thatcher, A. (2002). Living Together and Christian Ethics. London: Oxford University Press.

Thatcher, D. (2000). "Marriage after Modernity: Christian Marriage in Post Modern Time". London: Sheffield Academic Press.

Thornton, A. \& Axinn, W. (2006). "Marriage and Cohabitation in Chicago: University of Chicago." American Journal of Sociology, 98, 628.

Thornton, A; Axinn, W. (1993). "Reciprocal effects of religiosity, cohabitation, and marriage". American Journal of Sociology. 98 (3): 628651. doi:10.1086/230051. JSTOR 2781460.

Worku, S.V. \& Gustaffon, S. (2006). "Marriage Markets and Single Motherhood in South Africa. Tinbergen Institute of Discussion Paper, viewed 11 May, 2019, from http://www.libergen.nl/discussionpapers/06/02-pdf.

World Health Organization. (2001). Sexual Relations among Young People in Developing Countries: Evidence from WHO case studies. Geneva: WHO. 
Iyekolo

Wu, Z. M. J. Penning, M. S. Pollard \& R. Hart. 2003. "In Sickness and in Health": Does Cohabitation Count?” Journal of Family Issues, 24: 811-838. 